\title{
KONSEP KAWASAN WISATA BERBASIS BUDAYA “RT DOLANAN NUSANTARA"
}

\author{
Mohammad Reza \\ Dosen Prodi Perencanaan Wilayah dan Kota, Fak. Teknik Sipil dan Perencanaan, \\ ITN Malang \\ e-mail: reza@ftsp.itn.ac.id \\ Maria Christina Endarwati \\ Dosen Prodi Perencanaan Wilayah dan Kota, Fak. Teknik Sipil dan Perencanaan, \\ ITN Malang \\ e-mail: endarwati@hotmail.com \\ Arif Setyawan \\ Dosen Prodi Perencanaan Wilayah dan Kota, Fak. Teknik Sipil dan Perencanaan, \\ ITN Malang \\ e-mail: arf_setiyawan@yahoo.com
}

\begin{abstract}
ABSTRAK
Pariwisata adalah suatu aktivitas perubahan tempat tinggal sementara dari seseorang, di luar tempat tinggal sehari-hari dengan suatu alasan apapun selain melakukan kegiatan yang bisa menghasilkan upah atau gaji. Selain itu, pariwisata merupakan aktivitas, pelayanan dan produk hasil industri pariwisata yang mampu menciptakan pengalaman perjalanan bagi wisatawan. Tujuan dari Pengabdian Kepada Masyarakat yaitu untuk mengetahui penerapan prinsip Landscape dalam perencanaan kawasan wisata berbasis budaya di Kelurahan Tasikmadu. Metode pelaksanaan yang digunakan adalah dengan melakukan pengelolaan destinasi pariwisata berkelanjutan, pemanfaatan ekonomi untuk masyarakat lokal, pelestarian budaya bagi masyarakat dan pengunjung serta pelestarian lingkungan dan membuat skenario pariwisata, yang diwujudkan dalam desain dan perencanaan pariwisata secara spesifik. Perencanaan Landscape dengan memerhatikan keadaan fisik wilayah menjadi modal perencanaan konsep wisata berbasis budaya. Salah satunya yaitu, pemilihan arah hadap Kawasan Wisata "RT Dolanan Nusantara" yang juga mempertimbangkan keberadaan Gunung Arjuna yang dapat terlihat dari lokasi perencanaan, sehingga menambah nilai keindahan bagi "RT Dolanan Nusantara".
\end{abstract}

\section{Kata kunci: Kawasan, Wisata Budaya, RT Dolanan Nusantara}

\begin{abstract}
Tourism is a change activity of temporary residence of a person, outside the daily residence for any reason other than carrying out activities that can generate wages or salaries. In addition, tourism is an activity, service and product from the tourism industry that is able to create a travel experience for tourists. The purpose of Community Service is to find out the application of Landscape principles in the planning of cultural-based tourism areas in the Tasikmadu Village. The method of implementation used is to manage sustainable tourism destinations, economic use for local communities,
\end{abstract}


cultural preservation for the community and visitors as well as environmental preservation and create tourism scenarios, which are manifested in the specific design and planning of tourism. Landscape Planning by paying attention to the physical condition of the region becomes the capital for planning cultural-based tourism concepts. One of them is choosing the direction towards the "RT Dolanan Nusantara" Tourism Area which also considers the existence of Mount Arjuna which can be seen from the planning location, thus adding to the beauty value for "RT Dolanan Nusantara".

\section{Keywords : Area, Cultural Tourism, RT Dolanan Nusantara}

\section{PENDAHULUAN}

Kegiatan wisata merupakan suatu kegiatan perjalanan baik individu maupun grup dari tempat tinggal menuju suatu tempat tertentu untuk mendapatkan pengalaman diluar aktivitas kesehariannya (seperti: bekerja, sekolah, mengurus rumah tangga dll) dalam waktu yang sementara. Pariwisata saat ini, sudah menjadi salah satu kebutuhan tidak hanya bagi masyarakat di negara maju. Hal ini terjadi, karena sektor pariwisata secara signifikan dapat mendorong kemajuan ekonomi di suatu wilayah, baik secara makro maupun mikro. Secara makro sektor pariwisata dapat meningkatkan nilai PDRB. Sementara secara mikro, sektor pariwisata dapat membuka lapangan pekerjaan dan mendorong kegiatan perdagangan dan jasa. Objek dan daya tarik wisata merupakan salah satu unsur penting dalam dunia kepariwisataan. Objek dan daya tarik wisata dapat berupa alam, budaya, tata hidup dan sebagainya yang memiliki daya tarik dan nilai jual untuk dikunjungi ataupun dinikmati oleh wisatawan. Oleh karena itu, kebudayaan dan keberagaman sebagai citra Indonesia dapat diimplementasikan dalam perencanaan destinasi wisata berbasis budaya.

Kelurahan Tasikmadu merupakan kelurahan yang terletak di wilayah Kecamatan Lowokwaru, Kota Malang. Wilayah RT 04 RW 03 Kelurahan Tasikmadu merupakan wilayah yang cukup strategis, karena lokasi tersebut memiliki potensi perkembangan yang sangat besar, terutama di sektor pertanian serta budaya. Dengan adanya potensi tersebut dan didukung dengan keadaan fisik wilayah yang ada menjadi modal perencanaan konsep wisata berbasis budaya, maka Wilayah RT 04 RW 03 Kelurahan Tasikmadu berpotensi untuk dikembangkan menjadi kawasan wisata "RT Dolanan Nusantara", dikarenakan di wilayah tersebut terdapat salah satu produksi kuda jaranan serta produksi makanan tradisional.

Dari beberapa potensi yang ada diatas, maka dapat merumuskan permasalahan yang ada: bagaimana menyusun Konsep Kawasan Wisata Berbasis Budaya "Rt Dolanan Nusantara" di Kelurahan Tasikmadu Kecamatan Lowokwaru, Kota Malang. 


\section{TINJAUAN PUSTAKA}

\subsection{Kegiatan Wisata}

Kegiatan wisata merupakan suatu kegiatan perjalanan baik individu maupun grup dari tempat tinggal menuju suatu tempat tertentu untuk mendapatkan pengalaman diluar aktivitas kesehariannya (seperti: bekerja, sekolah, mengurus rumah tangga dII) dalam waktu yang sementara. Dari pengertian mengenai kegiatan wisata tersebut terlihat beberapa komponen penting yang menjadikan proses tersebut terjadi. Komponen-komponen tersebut adalah: tempat tinggal, perjalanan, pelaku perjalanan wisata, dan tempat tujuan. (Nurdin, 2019)

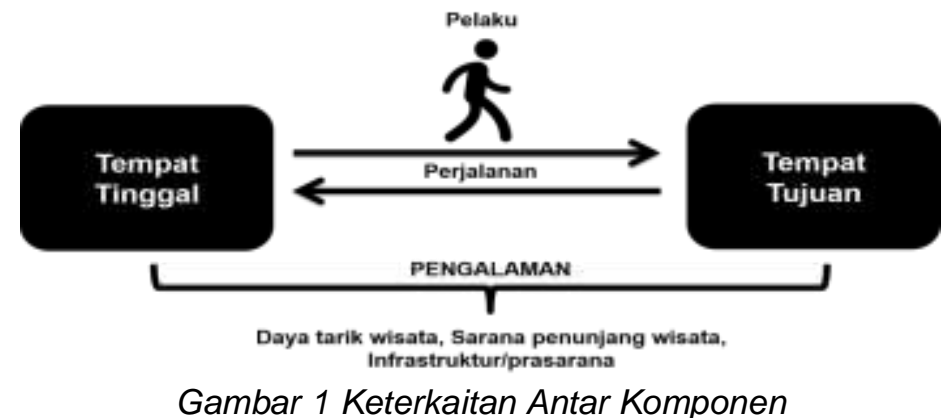

\subsubsection{Daya Tarik Wisata}

Daya tarik pariwisata adalah hal-hal yang menarik perhatian wisatawan yang dimiliki oleh suatu daerah tujuan wisata. (Spillane, 2002). Daya tarik wisata juga merupakan segala sesuatu yang menarik dan menghasilkan pengalaman kepada pelaku perjalanan wisata, baik secara pasif maupun aktif, contoh: keindahan pantai, suasana pegunungan, gerhana, pentas seni, event olahraga, karnaval, menunggangi kuda, mendaki gunung, berselancar, bercengkrama dengan masyarakat, dll. (Nurdin, 2019)

\subsubsection{Sarana Penunjang Wisata}

Sarana wisata merupakan kelengkapan daerah tujuan wisata yang diperlukan untuk melayani kebutuhan wisatawan dalam menikmati perjalanan wisatanya. Suwantoro (2004:22). Sarana penunjang wisata juga merupakan segala sesuatu yang dapat memfasilitasi kegiatan wisata baik yang dapat diindera (tangible) maupun yang tidak dapat diindera (intangible), contoh: jasa transportasi, akomodasi, makan/minum, toilet, pramuwisata (guide), informasi dll. (Nurdin, 2019)

\subsubsection{Infrastruktur / Prasarana}


Prasarana (infrastruktur) wisata adalah sumber daya alam dan sumber daya manusia yang mutlak dibutuhkan oleh wisatawan dalam perjalanannya di daerah tujuan wisata, seperti jalan, listrik, air, telekomunikasi, terminal, jembatan, dan lain sebagainya. (Suwantoro 2004)

\subsection{Destinasi Wisata Berbasis Budaya}

Wisata budaya, yaitu perjalanan yang dilakukan atas dasar keinginan untuk memperluas pandangan hidup seseorang dengan cara mengadakan kunjungan ke tempat lain atau ke luar negeri, mempelajari keadaan rakyat, kebiasaan dan adat istiadat mereka, cara hidup mereka, kebudayaan dan seni mereka. (Pendit, 2002). Pariwisata budaya juga merupakan jenis obyek daya tarik wisata yang berbasis pada hasil karya cipta manusia baik yang berupa peninggalan budaya maupun nilai budaya yang masih hidup sampai sekarang. (Sunaryo 2013).

Salah satu jenis pariwisata diantaranya yaitu, pariwisata budaya yang memanfaatkan perkembangan potensi hasil budaya manusia sebagai daya tariknya. Jenis wisata ini dapat memberikan manfaat dalam bidang sosial budaya karena dapat membantu melestarikan warisan budaya sebagai jati diri masyarakat lokal yang memiliki kebudayaan tersebut.

Penetapan wisata budaya harus dapat memenuhi persyaratan, sebagai berikut:
a. Aksesibilitas yang baik
b. Memiliki objek yang menarik
c. Masyarakat dan aparat desa dapat menerima dengan baik wisatawan
d. Terjaminnya keamanan
e. Tersedianya akomodasi, telekomunikasi dan tenaga kerja yang memadai

\section{METODE PENELITIAN}

\subsection{Lokasi Penelitian}

Lokasi penelitian berada di RT 04 RW 03 Kelurahan Tasikmadu Kecamatan Lowokwaru Kota Malang.

\subsection{Pengumpulan Data}

Kegiatan ini dimaksudkan untuk mengumpulkan dan memperoleh data yang dibutuhkan dalam penelitian. Pengumpulan data ini dibagi dalam dua bagian pokok, yaitu: pengumpulan data primer dan pengumpulan data sekunder. Pengumpulan data primer meliputi: observasi (pengamatan) secara langsung, tujuannya untuk mengetahui kondisi lokasi penelitian dan melakukan wawancara pada masyarakat di lokasi penelitian, sedangkan pengumpulan data sekunder meliputi: penelaahan kepustakaan untuk penyusunan landasan teori dan survey instansi, dimana data-data dapat diperoleh dari instansi pemerintah maupun perusahaan swasta kemudian data yang diperoleh tersebut dapat dianalisa. 


\subsection{Metode Analisa}

Metode analisa dalam penelitian menggunakan metode kualitatif ini juga berdasarkan kondisi eksisting dari wilayah-wilayah penelitian, misalnya konsep disain yang diinginkan oleh masyarakat, yang akan disesuaikan dengan kondisi di lapangan.

\section{HASIL DAN PEMBAHASAN}

\subsection{Konsep "RT Dolanan Nusantara"}

Pengembangan pariwisata akan memiliki dampak bagi masyarakat, sama halnya dengan pembangunan pada sektor lain. Baik secara positif maupun negatif. Untuk itu, diperlukan adanya perencanaan secara menyeluruh untuk dapat mengoptimalkan dampak positif serta meminimalisir dampak negatif.

Kelurahan Tasikmadu, khususnya pada wilayah RT 04 RW 03 merupakan wilayah yang cukup strategis, mengingat dekatnya lokasi dengan fasilitas pendidikan yaitu Kampus II Institut Teknologi Nasional Malang. Dikarenakan letaknya yang sangat strategis tersebut, RT 04, RW 03 Kelurahan Tasikmadu memiliki potensi perkembangan yang sangat besar. Potensi tersebut dapat dikembangkan secara terintegrasi dengan pembangunan sektor ekonomi, industri, perdagangan, pertanian dan sektor pariwisata.

RW 03 Kelurahan Tasikmadu memiliki potensi di sektor pertanian serta budaya. Dimana salah satu produksi kuda jaranan serta produksi makanan tradisional terdapat di RT 04

RT 04 RW 03 Kelurahan Tasikmadu. Pengembangan Kawasan Wisata di RT 04 RW 03 Kelurahan Tasikmadu akan dapat memiliki daya tarik yang tinggi apabila dikelola secara profesional serta memberikan manfaat bagi masyarakat sekitar. Potensi yang dapat dikembangkan di RT 04 RW 03 Kelurahan Tasikmadu yaitu: mempunyai latar belakang Gunung Arjuna, Kekayaan sosial, seni dan budaya masyarakat setempat, Pemanfaatan lahan sebagai kawasan pertanian.

\subsection{Tourism Scenario}

Tourism Scenario diartikan sebagai skenario pariwisata, yang diwujudkan dalam desain dan perencanaan pariwisata secara spesifik. RT Dolanan Nusantara terdiri dari beberapa wahana yang bersifat tematik.

\subsubsection{Gapura RT Dolanan Nusantara}


Gapura masuk utama RT Dolanan Nusantara bertuliskan "Sugeng Rawuh" yang di ambil dari Bahasa jawa yang memiliki arti "Selamat Datang" dan juga di hiasi dengan patung singa yang identik dengan lambang dari Kota Malang pada jaman dahulu serta pada nama suatu kerajaan yang pernah ada di Malang yaitu Singosari.

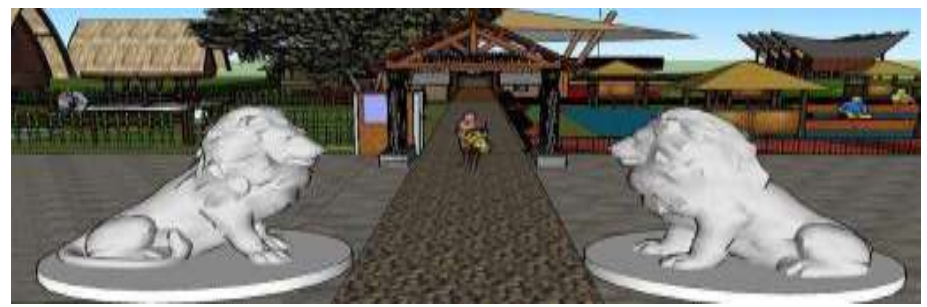

Gambar 2 Gapura RT Dolanan Nusantara

\subsubsection{Panggon Dolanan Jawa Barat}

Kegiatan yang terdapat di Panggon dolanan Jawa Barat yaitu kegiatan membatik motif mega mendung yang menjadi ciri khas dari daerah Cirebon. Adapun kegiatan lain yang terdapat di Panggon Dolanan Jawa Barat yaitu, pasar apung. Penerapan pasar apung, dimaksudkan secara simbolis mewakili pandangan masyarakat sunda terhadap air, tidak hanya sebagai identitas komunitas, tradisi ritual dan pandangan hidup tetapi juga penghias mitos yang berkembang di masyarakat. Pengunjung juga dapat mempelajari kesenian Jawa Barat lainnya seperti kesenian musik Jawa Barat, diantaranya: suling, kecapi dan angklung.

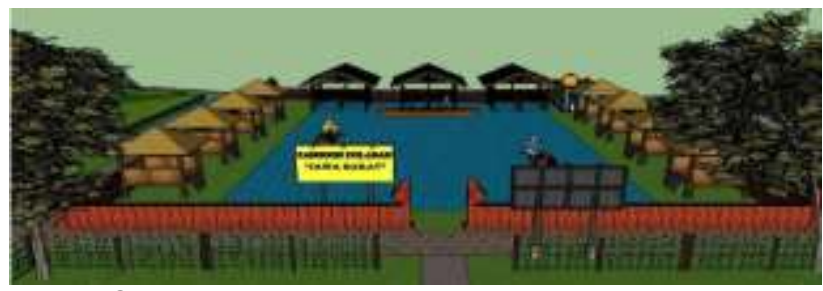

Gambar 2 Panggon Dolanan Jawa Barat

Berikut rincian kegiatan wisatawan di Panggon Dolanan Jawa Barat :

a. Wahana Pasar Apung

Wisatawan dapat berbelanja dengan mengendarai sampan untuk menuju Pasar Apung.

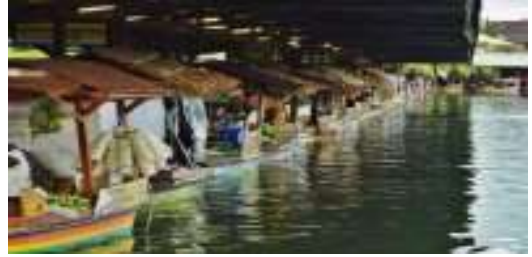

Gambar 3 Pasar Apung

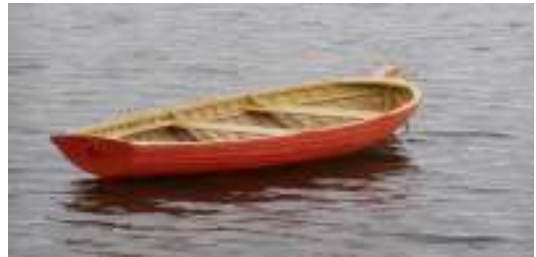

Gambar 4 Wahana Sampan

PAWON: Jurnal Arsitektur, Volume II Nomor 02, Juli-Desember 2018, ISSN 2597-7636 


\section{b. Wahana Sepeda Air}

Wisatawan dapat mengendarai Sepeda air yang tersedia di Panggon Dolanan Jawa Barat.

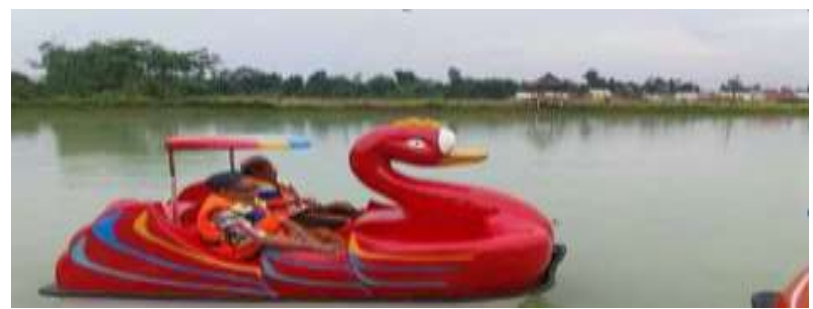

Gambar 5 Wahana Sepeda Air

\section{c. Membatik}

Wisatwan dapat membuat batik dengan motif khas Jawa Barat yaitu motif mega mendung, dalam proses membatik wisatawan disediakan alat membatik dan boleh membawa hasil karya sebagai cenderamata.

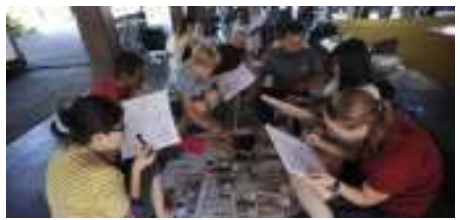

Gambar 6 Kegiatan Membatik

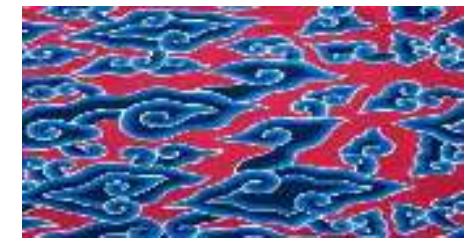

Gambar 7 Batik Mega Mendung

\section{d. Kegiatan Belajar Alat Musik}

Kegiatan belajar Alat Musik Tradisional Jawa Barat yang akan dilakukan pada saung di sisi sebelah kanan dan kiri Panggon Dolanan Jawa Barat. Kapasitas pada tiap saung adalah 5-7 peserta untuk saung yang berukuran kecil di sisi sebelah kanan dan kiri Panggon Dolanan Jawa Barat. Sementara untuk saung berukuran besar dapat menampung 15 20 orang untuk tiap saung.

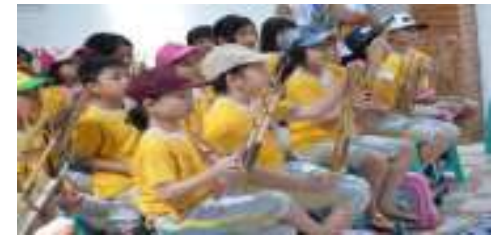

Gambar 8 Alat Musik Tradisional Angklung

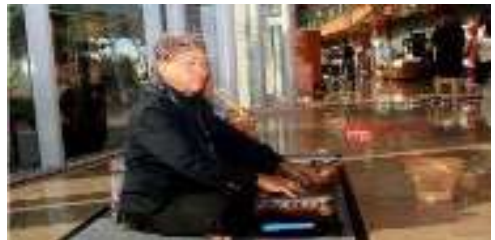

Gambar 9 Alat Musik Tradisional Kecapi

Jurnal PAWON, Nomor 02 Volume IV, Bulan Juli-Desember Tahun 2020, ISSN 2597-7636 


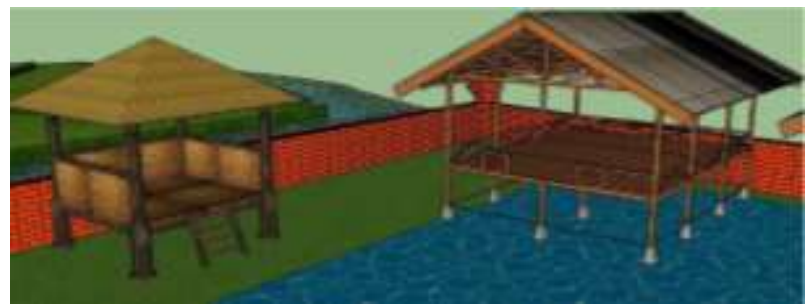

Gambar 10 Saung

\subsubsection{Panggon Dolanan Lombok}

Kegiatan yang terdapat di Panggon Dolanan Lombok yaitu, permainan begasingan. Dimana pengunjung dapat mencoba secara langsung permainan tersebut. Nantinya, permainan akan dimainkan lebih dari 5 orang secara bersamaan dengan dibagi menjadi dua tim. Penentuan pemenang dilakukan dengan, melihat tim mana yang akan memiliki gasing yang paling terakhir bertahan.

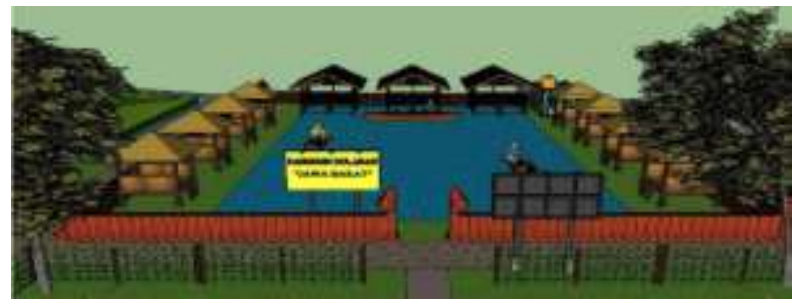

Gambar 11 Panggon Dolanan Lombok

Berikut rincian kegiatan wisatawan di Panggon Dolanan Lombok :

\section{a. Pembuatan Gasing}

Wisatawan dapat mengecat gasing sesuai dengan keinginan masingmasing dipandu oleh pembuat gasing. Wisatawan juga dapat belajar dan melihat proses pemahatan gasing

Kegiatan mengecat gasing dan melihat proses pembuatan gasing dilakukan di Rumah Adat Bale Geleng yang terdapat di sisi sebelah kanan dan kiri Panggon Dolanan Lombok. Masing-masing rumah adat memiliki kapasitas $20-25$.

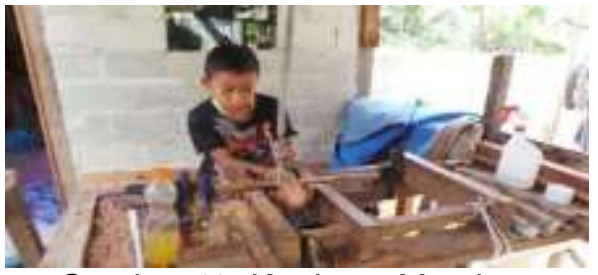

Gambar 12 Kegiatan Membuat Gasing

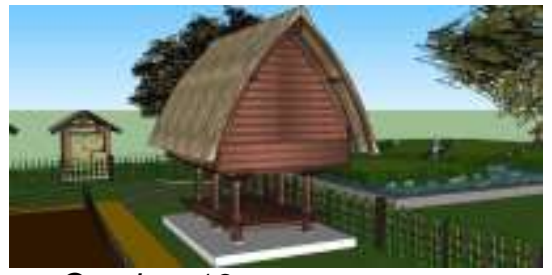

Gambar 13 Rumah Adat Bale Geleng 


\section{b. Begasingan}

Setelah wisatawan membuat gasing, wisatawan dapat bermain gasing dipandu oleh guide untuk belajar memainkan gasing dengan waktu 30 menit.

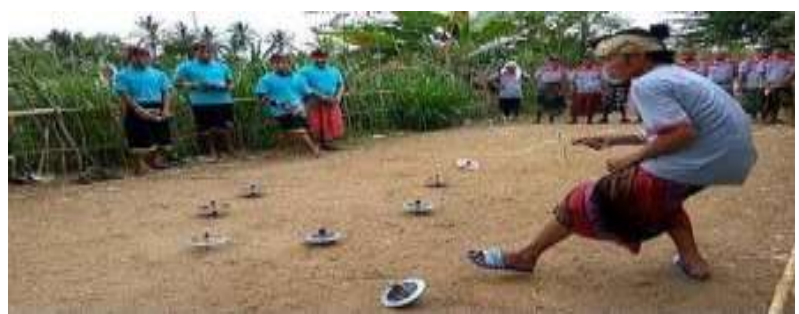

Gambar 14 Begasingan

\subsubsection{Panggon Dolanan Toraja}

Kegiatan yang terdapat di Panggon Dolanan Toraja yaitu permainan "sisemba". Permainan ini dimainkan oleh 6 tim, dimana 1 tim beranggotakan 5 orang yang saling berpegangan. Aturan mainan "sisemba" adalah tiap tim atau tiap anggota dapat menendang tim lawan di bagian badan sampai kaki, jika tim lawan atau anggota tim lawan terjatuh maka akan dikeluarkan dari arena permainan. Pemenang dari permainan ini adalah tim atau anggota tim yang dapat bertahan hingga akhir permainan.

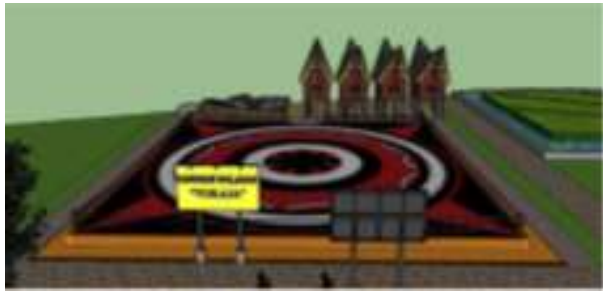

Gambar 15 Panggon Dolanan Toraja

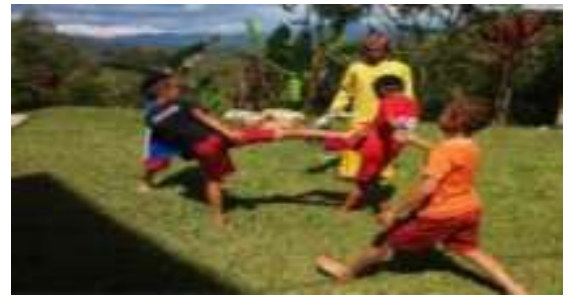

Gambar 16 Permainan Sisemba

Adapun Rumah Adat Tongkonan yang difungsikan untuk tempat menonton "sisemba" dan juga tempat berswafoto dapat menampung 20 orang pada masing-masing Rumah Tongkonan.

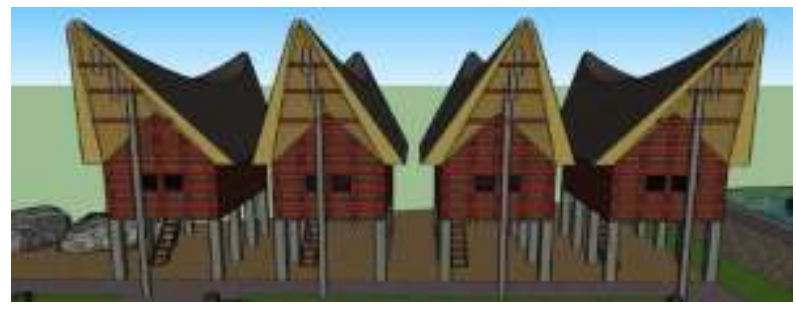

Jurnal PAWON, Nomor 02 Volume IV, Bulan Juli-Desember Tahun 2020, ISSN 2597-7636 


\subsubsection{Panggon Dolanan Melayu}

Panggon Dolanan Melayu akan diisi dengan kegiatan permainan Ligu, Wau dan Statak.

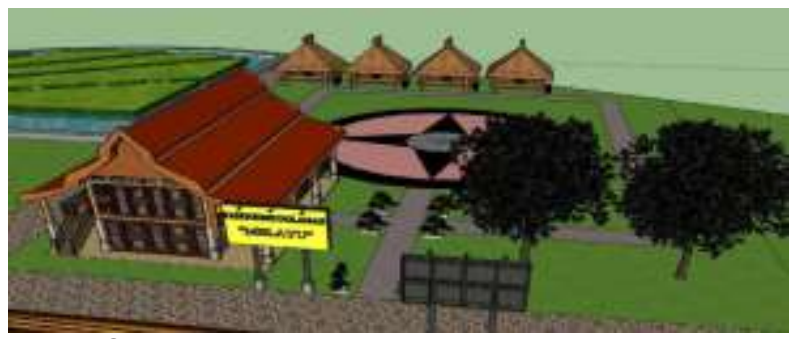

Gambar 18 Panggon Dolanan Melayu

\section{a. Permainan Ligu}

Ligu merupakan jenis permainan yang terbuat dari bambu sebagai pemukul dan juga tempurung kelapa yang dibentuk menyerupai wajik dan hati. Ligu dimainkan oleh 2 orang atau 2 kelompok. Ligu biasa dimainkan di tanah yang lapang dengan membuat garis kira-kira 1 meter lalu diletakkan Ligu digaris secara berjejer. Pemain berkumpul antara 2 orang atau 2 kelompok dengan melakukan amplong dengan menggunakan telapak tangan untuk menentukan pemenangnya. Bila dinyatakan galah maka Ligunya dipasangkan pada tempat yang ditentukan dan yang menang dialah yang pertama kali memukul. Sipemukul menggunakan ligunya lalu dipukul menggunakan alat pemukul yang terbuat dari bambu (teta) ke arah ligu lawan yang telah dipasangkan tadi. Jika dapat mengena ligu lawan berarti dia mendapatkan poin (bintang), jika tidak mengena maka gantian main, demikian seterusnya, pemenangya adalah yang banyak mendapatkan point.

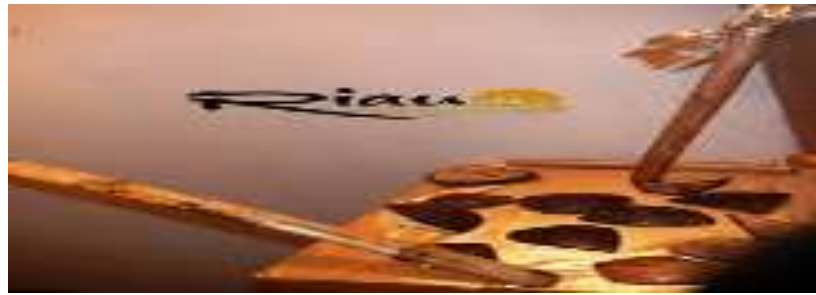

Gambar 19 Permainan Ligu

\section{b. Permainan Wau}

Permainan Wau ini juga dikenali dengan layang-layang. Permainan Wau amat digemari oleh penduduk-penduduk kampung. Permainan ini dimainkan sejak kurun ke 15. Wau mempunyai bermacam-macam bentuk dan mempunyai nama tersendiri seperti Wau Burung, Wau Pari, Wau Katak, Wau Bayan, Wau Merak, Wau Kucing, Wau Jala Budi, Wau 
Lenggang Kebayan, Wau Sewah dan Wau Barat.

Pada kebiasaannya Wau akan dimainkan oleh dua orang yaitu seorang akan memegang Wau dan seorang lagi yang dipanggil juru anjung akan memegang tali. Apabila angin bertiup maka tali akan ditarik melawan arus angin dengan cara menghulur dan menarik talinya sehinggalah Wau tersebut tinggi di udara. Kilauan cahaya matahari akan menambah cantik lagi Wau yang berwarna-warni itu.

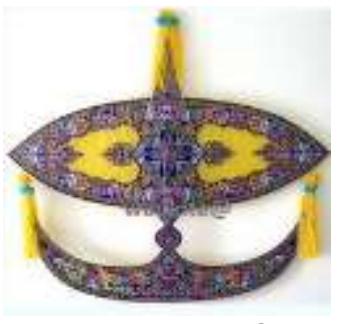

Gambar 20 Permainan Wau

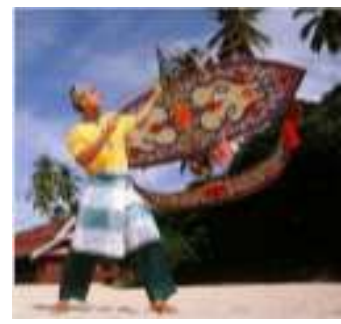

\section{c. Permainan Statak}

Permainan Statak atau Engklek adalah suatu permainan tradisional lompat-lompatan pada bidang datar yang digambar di atas tanah dengan membuat gambar kotak-kotak, kemudian melompat dengan satu kaki dari kotak satu ke kotak berikutnya.

Bahannya terbuat dari Batu yang pipih dan juga bisa pecahan piring atau kaca yang kemudian disebut dengan ucak, kemudian diatas tanah dibuat garis yang dibentuk sesuai permainan, umumnya permainan ini dimainkan oleh anak perempuan, walaupun anak laki-laki juga sering ikut bermain.
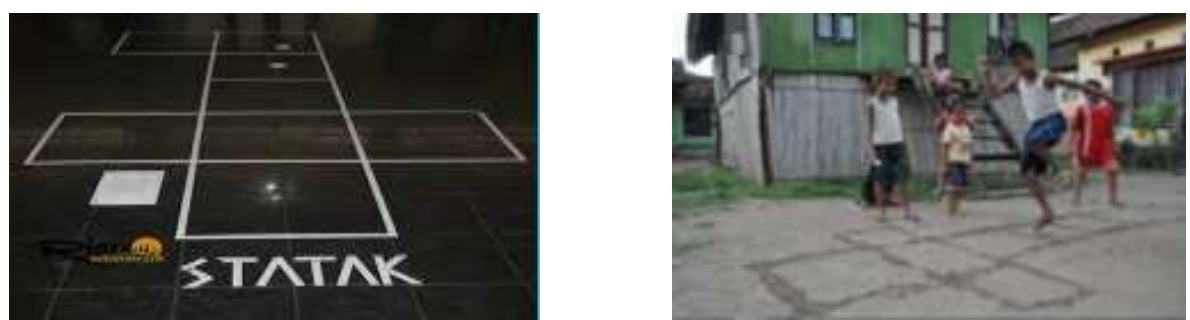

Gambar 21 Permainan Statak

\section{d. Rumah Adat Alor}

Rumah Adat Alor berada di Kawasan Tematik Panggon Dolanan Melayu, fungsi Rumah Adat Alor adalah sebagai tempat menonton kegiatan yang ada di Panggon Dolanan Melayu serta tempat istirahat bagi pengunjung 
yang telah mengunjungi Tiga Panggon Dolanan sebelumnya. Dengan luas masing-masing alor seluas 6,5 × 6,5 meter maka tiap 1 unit Rumah Adat Alor memiliki kapasitas hingga 8 orang dewasa.

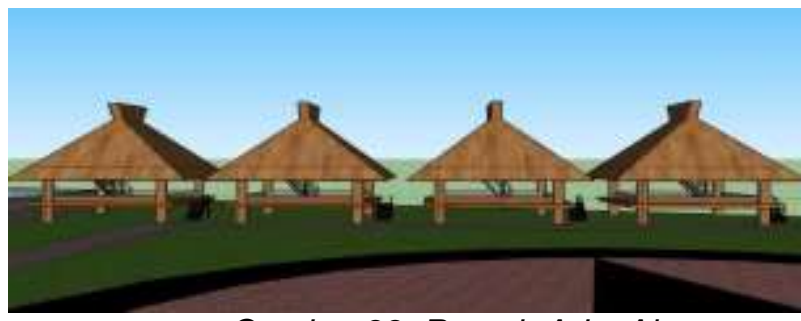

Gambar 22 Rumah Adat Alor

\subsubsection{Panggon Gayatri Upangga Rastika}

Panggung Gayatri Upangga Rastika, hanya akan dibuka pada hari minggu dengan pertunjukkan seni utama yaitu topeng malangan serta diselingi dengan pertunjukkan seni dari masing-masing daerah sesuai tematik tiap wahana.

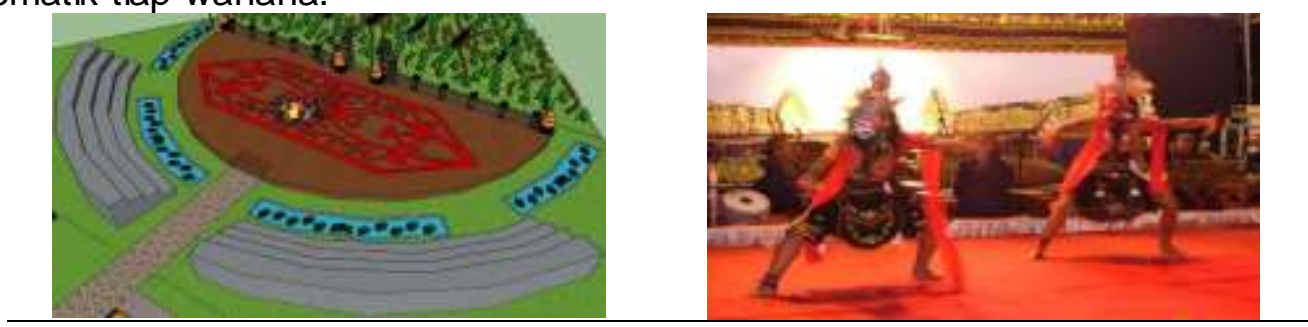

Gambar 23 Panggon Gayatri Upangga Rastika

Gambar 24 Tari Topeng Malangan

\section{KESIMPULAN}

Upaya pelestarian budaya dalam sektor pariwisata dapat dilakukan dengan konsep penggabungan unsur-unsur budaya dalam tematik suatu objek pariwisata, sehingga dapat menjadi nilai tambah bagi unsur atraktsi pada objek wisata tersebut. Disamping itu, dalam proses perencanaan suatu objek wisata juga perlu dilakukan perencanaan secara matang terkait rincian kegiatan yang tertuang dalam tourism scenario. Tourism scenario dilakukan dengan mempertimbangkan wisatawan sebagai bagian dari perencanaan suatu destinasi wisata, sehingga tema dan jarak yang harus ditempuh oleh pengunjung merupakan komponen yang dapat menjadi pertimbangan utama. Pertimbangan terhadap jarak adalah salah satu upaya yang dapat dilakukan untuk memberikan kenyamanan bagi wisatawan sehingga wisatawan dapat memahami konten pariwisata yang tidak hanya disampaikan melalui wahana permainan tapi juga konsep lansekap sebagai bagian dari tema.

\section{DAFTAR PUSTAKA}


Erwan Melaka, 2016, Bermain Layang Wau hingga Malam di Bengkalis

Fandeli Chafid. 2002, Perencanaan Kepariwisataan Alam. Yogyakarta:

Fakultas Kehutanan Universitas Gadjah Mada.

Haryo Prasetyo dan Dr. Ing. Ir. Haryo Sulistiyarso. 2017. Arahan

Pengembangan Kawasan Desa Wisata di Desa Tulung Rejo

Kecamatan Pare Kabupaten Kediri. Jurnal Teknik ITS, Institut

Teknologi Sepuluh November, Surabaya Vol 6. No 2, 2337-3520.

Hidayah, Nurdin (2019). Pemasaran Destinasi Pariwisata. Bandung: Alfabeta

Helln Angga Devy, R.B. Soemanto. 2017. Pengembangan Obyek Dan Daya

Tarik Wisata Alam Sebagai Daerah Tujuan Wisata Di Kabupaten

Karanganyar. Jurnal Sosiologi DILEMA, Universitas Sebelas Maret, Surakarta Vol. 32, No. 1, 34-44.

Marios Lublinski. 2016, Jenis-Jenis Permainan Tradisional Masyarakat Melayu Riau

Mas Sugeng, 2016, Floating Market Lembang, Wisata Pasar Terapung di Bandung Yang Menyenangkan

Mikhael Gewati, Palupi Annisa Auliani, 2016, Apa Kabar Tradisi "Baku Tendang" Tana Toraja?

Monica Dian, 2015, Batik Mega Mendung, Warisan Pernikahan Beda Agama dan Beda Budaya

Rohman, SM., 2015, Begini Cara Membuat Gasing ala Budak-Budak di Anambas.

Pitana, I. Gede dan Gayatri, Putu G. 2005. Sosiologi Pariwisata. Yogyakarta: Andi,

Pendit, Nyoman S. 2006. Ilmu Pariwisata. PT Pradnya Paramita. Jakarta.

Rohman, SM., 2015, Begini Cara Membuat Gasing ala Budak-Budak di Anambas

Siti Rutmawati, 2016, Menelisik Sejarah Tari Topeng Malangan

Spillane, James. J. 2002. Ekonomi Pariwisata Sejarah dan Prospeknya. Yogyakarta : Karnisius

Sunaryo, Bambang. 2013. Kebijakan Pembangunan Destinasi Pariwisata

Konsep dan Aplikasinya di Indonesia. Yogyakarta : Gava Media.

Suwantoro, Gamal. 2004. Dasar-dasar Pariwisata. Yogyakarta: Andi Offset.

Wilopo,K.K dan Hakim, Luchman. Strategi Pengembangan Destinasi

Pariwisata Budaya.Vol. 41 No.1 Januari 2017 
